\title{
Single nucleotide polymorphisms, haplotypes and combined genotypes in MYH3 gene and their associations with growth and carcass traits in Qinchuan cattle
}

\author{
Lijun Wang Xiaolin Liu $\cdot$ Fubiao Niu \\ Hongliang Wang $\cdot$ Hua He $\cdot$ Yulan Gu
}

Received: 29 April 2012/ Accepted: 3 October 2012/Published online: 17 October 2012

(C) The Author(s) 2012. This article is published with open access at Springerlink.com

\begin{abstract}
MYH}_{3}$ is a major contractile protein which converts chemical energy into mechanical energy through the ATP hydrolysis. $\mathrm{MYH}_{3}$ is mainly expressed in the skeletal muscle in different stages especially embryonic period, and it has a role in the development of skeletal muscle and heart. In this study, polymerase chain reactionrestriction fragment length polymorphism (PCR-RFLP) was applied to analyze the genetic variations of the $\mathrm{MYH}_{3}$ gene and verify the effect on growth and carcass traits in a total of 365 Qinchuan cattles. The PCR product was digested with some restriction enzyme and demonstrated the polymorphism in the population, the single nucleotide polymorphisms (SNPs) at nucleotides g. $+1215 \mathrm{~T}>\mathrm{C}$, g. $+3377 \mathrm{C}>\mathrm{T}$, and g. $+28625 \mathrm{C}>\mathrm{T}$ were in linkage disequilibrium with each other. The result of haplotype analysis showed that nineteen different haplotypes were identified among the five SNPs. The statistical analyses indicated that the five SNPs were significant association with growth and carcass traits $(P<0.05, N=365)$; whereas the five SNPs were no significant association between 18 combined genotypes of $\mathrm{MYH}_{3}$ gene and growth and carcass traits. Taken together, our results provide the evidence that polymorphisms in $\mathrm{MYH}_{3}$ are associated with growth and carcass traits in Qinchuan cattle, and may be used as a possible candidate for marker-assisted selection and management in beef cattle breeding program.
\end{abstract}

Keywords Qinchuan cattle - Growth and carcass traits . Combined genotypes $\cdot$ Haplotype $\cdot \mathrm{MYH}_{3}$

L. Wang $\cdot$ X. Liu $(\bowtie) \cdot$ F. Niu $\cdot$ H. Wang $\cdot$ H. He $\cdot$ Y. Gu

College of Animal Science and Technology,

Northwest A\&F University, Yangling 712100, Shaanxi,

People's Republic of China

e-mail: liuxiaolin@nwsuaf.edu.cn

\author{
Abbreviations \\ PCR-RFLP Polymerase chain reaction-restriction \\ fragment length polymorphism \\ SNPs Single nucleotide polymorphisms \\ $\mathrm{MyHC} \quad$ Myosin heavy chain \\ $\mathrm{MYH}_{3} \quad$ Myosin heavy chain 3 \\ $H M M \quad$ Heavy meromyosin \\ LMM Light meromyosin \\ LD Linkage disequilibrium \\ $\mathrm{He} \quad$ Heterozygosity \\ Ho Homozygosity \\ PIC Polymorphism information content
}

\section{Introduction}

Multiple myosin isoforms are encoded by a multigene family and expressed in different developmental stages and fiber types. There are three skeletal fast myosin heavy chain (MyHC) genes (IIa, IIdx, and IIb), but only the promoter region of the mouse IIb gene has been analyzed to date [1-6]. The MyHCs encoded by a group of genes consisting of IIa, IIb [7], IIx [8], extraocular [9], embryonic [10] and neonatal [11] genes. These genes are located on the chromosome 14 [12], which expressed at different times during development and in different fiber types [13-16].

Myosin proteins consist of both heavy and light chains and are present in skeletal muscle. Heavy chains are associated with the speed of muscular contractions, while the role of light chains is not well defined [17]. Studies have shown that myosin heavy chain $3\left(\mathrm{MYH}_{3}\right)$ gene may be one of major genes implicated in the differences of 
muscle fiber property between intact males and castrated Qinchuan cattle [18]. The $M Y H_{3}$ is a major structural protein of the thick filament of the sarcomere. $M Y H_{3}$ gene is a member of the $M Y H$ family and encodes a protein with an IQ domain [19]. Polymorphism of $M H C$ isoform expression in single myofibers, which points out that single fibers of both developing and adult skeletal muscle exist as hybrids [20-23]. In a word, $\mathrm{MYH}_{3}$ gene is expressed during the embryonic period [24], at the same time, $\mathrm{MYH}_{3}$ has a role in skeletal muscle development $[13,25,26]$.

In human, the $\mathrm{MYH}_{3}$ gene is located on chromosome 17, and it is a molecular motor that converts chemical energy into mechanical force [27]. Conventionally, class II myosin is a hexameric protein composed of two $M y H C$ subunits, each with a molecular weight of approximately $220 \mathrm{kDa}$ and two pairs of non-identical myosin light chain subunits. Proteolytic enzymes can cleave the $M y H C$ into two subfragments: heavy meromyosin (HMM) and light meromyosin $(L M M)$. The expression of $M Y H_{3}$ is predominated in myotubes fated to become fast myofibers and is gradually replaced by the expressions of other myosin genes $\left(\mathrm{MYH}_{1}\right.$, $\mathrm{MYH}_{2}$ and $\mathrm{MYH}_{4}$ ) [28]. During the development and the adult, $\alpha-M Y H$ is predominately expressed in the atrial chamber and $\beta-M Y H$ in the ventricular chamber in both humans and chicks [29-33]. This is further illustrated by the increased expression of $\beta-M H C$ in the atria of human hearts under pressure overload [34, 35]. MHC analysis of human soleus muscle shows that this muscle expresses an approximately equal mix of type I and IIa isoforms, but the type IIx $M H C$ is not expressed [36]. In contrast, human fast muscles such as the vastus lateralis express a mix of all three types of $M H C$ isoforms at variable proportions [36, 37], depending on the physical fitness and activity of the subject. In addition, the study shows that knockdown in the early embryo leads to abnormal atrial septal development and heart enlargement [38]. These studies all point to the potentially vital function of $\mathrm{MYH}_{3}$ in regulating gene expression at the skeletal muscle and heart development.

In a rat model, the $\mathrm{MYH}_{3}$ gene is located on chromosome 10. It is an essential protein with skeletal muscle development. $\beta-M H C$ has been shown to be down-regulated in the setting of hypoxia, likely as a result of neuroendocrine stimulation [39]. Cytokines and tumor factors such as $T N F$ - $\alpha$ have been demonstrated to selectively target $\mathrm{MYH}_{2}$ gene and down-regulate transcription in a mouse model [40]. $\mathrm{MYH}_{3}$ is plastic in the adult rodent heart. In contrast to described human, the adult heart of small animals such as rodents and mice mainly expresses the $\alpha-M H C$ throughout the adult state. These results also support the idea that $\mathrm{MYH}_{3}$ plays an important role in heart development.

In this study, we used DNA sequencing, PCR-RFLP analysis to investigate allelic variation of $\mathrm{MYH}_{3}$ gene that encompasses five SNPs. Furthermore, we reported associations among these SNPs of the $\mathrm{MYH}_{3}$ gene in the Qinchuan cattle breed and the linkage disequilibrium between the variations and we analyzed the relationship between single nucleotide polymorphisms and growth and carcass traits.

\section{Materials and methods}

Animal source and preparation of DNA samples

Cattle from the Qinchuan (QC) commercial breeds were randomly selected, for a total of 365 animals. These animals (30 \pm 2 months of the age at slaughter) were reared in Shaanxi province, P.R. China. The growth traits (body length, withers height and hip width) and carcass traits (slaughter weight and carcass weight) were measured according to the criteria of GB/T17238-1998 Cutting Standard of Fresh and Chilled Beef in China (China Standard Publishing House). All experimental protocols and animal care were performed according to authorization granted by the Chinese Ministry of Agriculture. Genomic DNA was isolated from $2 \%$ heparin-treated blood samples and stored at $-80{ }^{\circ} \mathrm{C}$, following the standard procedures [41].

\section{PCR amplification and DNA sequencing analysis}

Primers used to amplify bovine $\mathrm{MYH}_{3}$ gene were designed from a published gene sequence (GenBank accession number NC_007317). Primers, restriction enzymes selected (ABI, Foster City CA), The primer sequences, location and fragment sizes were listed in Table 1. The detection of allelic variation at the SNPs were based on the electrophoretic pattern of the restriction enzyme-treated PCR products.

PCR amplifications were performed in a total volume of $15 \mu \mathrm{L}$, where the volume mixture contained: $50 \mathrm{ng}$ of genomic DNA as template, $10 \mathrm{mM}$ Tris- $\mathrm{HCl}$ buffer $(\mathrm{pH}$ 8.8), containing $50 \mathrm{mM} \mathrm{KCl}, 0.2 \mu \mathrm{M}$ of each primer, $200 \mu \mathrm{M}$ dNTP and $0.5 \mathrm{U}$ Taq DNA polymerase (MBI Fermentas, USA). The $\mathrm{Mg}^{2+}$ concentration was optimized for each primer set. PCR conditions were as follows: after an initial denaturation of $5 \mathrm{~min}$ at $95^{\circ} \mathrm{C}$, amplicons were generated for 35 cycles of $30 \mathrm{~s}$ at $94{ }^{\circ} \mathrm{C}, 30 \mathrm{~s}$ at an optimal annealing temperature, and $45 \mathrm{~s}$ at $72{ }^{\circ} \mathrm{C}$, followed by a 10 min final extension at $72{ }^{\circ} \mathrm{C}$.

Restriction fragment length polymorphism analysis was used to identify the genotypes of sequence variants. The PCR products were digested in a total volume of $10 \mu \mathrm{L}$ containing: $5 \mu \mathrm{L}$ of PCR product, three units of restriction enzyme $(0.3 \mu \mathrm{L}), 1 \mu \mathrm{L}$ of reaction buffer and $3.7 \mu \mathrm{L}$ of 
Table 1 Primer sets for PCR and PCR-RFLP used for genotyping SNPs detected in bovine $\mathrm{MYH}_{3}$ gene

\begin{tabular}{|c|c|c|c|c|c|c|}
\hline $\mathrm{SNP}_{\mathrm{S}}$ & $\begin{array}{l}\text { Amplified } \\
\text { region }\end{array}$ & Primer sequence $\left(5^{\prime}-3^{\prime}\right)$ & $\mathrm{AT}\left({ }^{\circ} \mathrm{C}\right)$ & $\begin{array}{l}\text { SAF } \\
\text { (bp) }\end{array}$ & PR & Genotype \\
\hline SNP1 & Exon5 & $\begin{array}{l}\text { AAAGCCCGAGTATCAGAACC } \\
\text { TCCAACAGCCTCATCAAACA }\end{array}$ & 57.4 & 435 & $R S a \mathrm{I}$ & $\begin{array}{l}\text { CC: } 228,207 \\
\text { CT: } 228,207, \\
150,78 \\
\text { TT: } 207,150, \\
78\end{array}$ \\
\hline SNP2 & Intron5 & $\begin{array}{l}\text { AAAGCCCGAGTATCAGAACC } \\
\text { TCCAACAGCCTCATCAAACA }\end{array}$ & 57.4 & 435 & Bst $\mathrm{XI}$ & $\begin{array}{l}\text { TT: } 435 \\
\text { TC: } 435,339 \text {, } \\
\quad 96 \\
\text { CC: } 339,96\end{array}$ \\
\hline SNP3 & Intron7 & $\begin{array}{l}\text { TTGCTGCAAATGGCATTATT } \\
\text { TGAGATTCCCAACAAAGAGG }\end{array}$ & 59.8 & 447 & $P V U \mathrm{II}$ & $\begin{array}{l}\text { GG: } 447 \\
\text { GC: } 447, \\
222,225 \\
\text { CC: } 222,225\end{array}$ \\
\hline SNP4 & Exon 14 & $\begin{array}{l}\text { TGGAGGATTTTCAGAGGGGT } \\
\text { TGATATGGGGTGACAAGTGG }\end{array}$ & 59.3 & 532 & $R S a \mathrm{I}$ & $\begin{array}{l}\text { CC:532 } \\
\text { CT:532, 364, } \\
168 \\
\text { TT:364, } 168\end{array}$ \\
\hline SNP5 & Exon 14 & $\begin{array}{l}\text { TGGAGGATTTTCAGAGGGGT } \\
\text { TGATATGGGGTGACAAGTGG }\end{array}$ & 59.3 & 532 & $\operatorname{Taq} \mathrm{I}$ & $\begin{array}{l}\text { CC: } 433,99 \\
\text { СТ: } 433,243, \\
190,99 \\
\text { TT: } 243,190, \\
99\end{array}$ \\
\hline
\end{tabular}

SNPs: single nucleotide

polymorphisms;

$\mathrm{SNP} 1=\mathrm{C} 1878 \mathrm{~T}$;

$\mathrm{SNP2}=\mathrm{T} 2010 \mathrm{C}$

$\mathrm{SNP} 3=\mathrm{G} 3746 \mathrm{C}$;

SNP4 = C7294T;

SNP5 $=$ C7315T

AT: annealing temperature, SAF: size of amplification fragment, PR: PCR-RFLP
( $n_{i}$ is the number of $i$ genotypic, " $\mathrm{N}_{i}$ " is the frequency of the $\mathrm{i}$ allele, " $\mathrm{N}$ " is the number of alleles)

(2) The pattern of pairwise linkage disequilibrium (LD) between the SNPs was measured by LD coefficient $\left(\mathrm{D}^{\prime}\right)$ and correlation coefficient $\left(r^{2}\right)$, the measurements were determined using the program Haploview (http://www.broad.mit.edu/mpg/haploview) [42].

(3) The $\chi^{2}$ test was used to determine Hardy-Weinberg equilibrium of the mutation. Population genetic indices, including heterozygosity $(\mathrm{He})$, homozygosity $(\mathrm{Ho})$, polymorphism information content $(P I C)$ and effective allele numbers $(\mathrm{Ne})$ were calculated according to Nei et al. [43]. The formulas were as follows:

$$
\begin{aligned}
H_{o} & =\sum_{i=1}^{n} P_{i}^{2} H_{e}=1-\sum_{i=1}^{n} P_{i}^{2} N e=1 / \sum_{i=1}^{n} P_{i}^{2} P I C \\
& =1-\sum_{i=1}^{m} P_{i}^{2}-\sum_{i=1}^{m-1} \sum_{j=i+1}^{m} 2 P_{i}^{2} P_{j}^{2}
\end{aligned}
$$

(" $\mathrm{P}_{\mathrm{i}}$ " is the frequency of the $\mathrm{i}$ allele, " $\mathrm{n}$ " is the number of alleles)

(4) Haplotypes were obtained for each animal using the PHASE computer program (Ver 2.1) [44].

$\mathrm{GF}_{\mathrm{i}}=\mathrm{n}_{\mathrm{i}} / \mathrm{NAF} \mathrm{AF}_{\mathrm{i}}=2 \mathrm{Nii}+\mathrm{Nij} / 2 \mathrm{~N}$ 
(5) The SPSS software (Version 16.0) was used to analyze the association between genotypes and traits in Qinchuan cattle.

(6) Combined genotypes of SNPs and growth traits association analyses were carried out to explore the possible interaction between the SNPs. The model was similar to that of single marker association analysis, except that the interaction between the two SVs was included as a fixed effect.

\section{Results}

Sequence variants identified of $\mathrm{MYH}_{3}$ gene

The bovine $\mathrm{MYH}_{3}$ gene located on chromosome 19, and has been revealed that it contained 42 exons and encoded 1249 amino acids. In the present study, Genomic DNA of Qinchuan breeds was successfully amplified using primer pairs for the $\mathrm{MYH}_{3}$ gene (Table 1).

In total, five variants including three exons and two introns mutation were identified in the study (Table 2). According to the information of cattle $\mathrm{MYH}_{3}$ (GenBank Accession number: NC_007317), the T2010C and G3746C mutations were in intron 5 and intron 7, respectively, while the C1878T, C7294T and C7315T mutations were in exon 5, exon 14 and exon 14, respectively. According to the sequence mutations, the PCR products could be digested with $R S a \mathrm{I}$, BstXI, PVUII and TaqI restriction enzymes. Distinct banding patterns were analyzed in this study and shown in Table 2. The SNPs of $\mathrm{g}$. $+1878 \mathrm{C}>\mathrm{T}$ and $\mathrm{g}$. $+7315 \mathrm{C}>\mathrm{T}$ resulted in synonymous mutations of Tyr626Tyr and Val2439Val, respectively, while the SNP of $\mathrm{g}$. +7294C $>\mathrm{T}$ brought a missense mutation Arg2432Cys. Interestingly, it was firstly found that five novel mutations could be detected by endonucleases restriction site in bovine $\mathrm{MYH}_{3}$ gene.

It was a very useful strategy to scan large sample size sequence mutations with the methods of DNA sequencing and PCR-RFLP, which would overcome the inaccuracy,

Table 2 Description of the SNPs at the bovine $\mathrm{MYH}_{3}$ gene

\begin{tabular}{|c|c|c|}
\hline SNPs name & Alleles & Amino acid change \\
\hline SNP1 C1878T & TAC/TAT & Tyr626Tyr \\
\hline SNP2 T2010C & 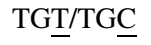 & - \\
\hline SNP3 G3746C & TGT/TCET & - \\
\hline SNP4 C7294T & $\underline{\text { CGT/TGT }}$ & Arg2432Cys \\
\hline SNP5 C7315T & CGA/TGA & Val2439Val \\
\hline
\end{tabular}

Note: SNPs: single nucleotide polymorphisms; SNP1 = C1878T; SNP2 $=$ T2010C $; \quad$ SNP3 $=$ G3746C $; \quad$ SNP4 = C7294T $; \quad$ SNP5 $=$ C7315T

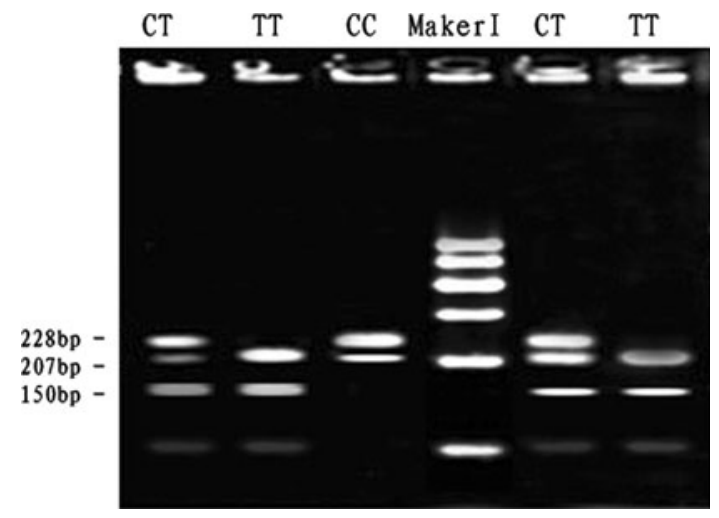

Fig. 1 The $3 \%$ agarose gels electrophoretic patterns of the $\mathrm{MYH}_{3}$ gene in bovine. $\mathrm{M}=\mathrm{DNA}$ molecular weight marker is Marker I; C1878T genotype: $\mathrm{CC}=228+207 \mathrm{bp}, \mathrm{TT}=207+150+78 \mathrm{bp}$, $\mathrm{CT}=228+207+150+78 \mathrm{bp}$; It is difficult to see the $78 \mathrm{bp}$ DNA fragment on $3 \%$ agarose gel. Forced PCR-RFLP detection results of $\mathrm{MYH}_{3}$ gene PCR product

the complicated technical demands, slow speed and unstable reproducibility. Interestingly, in this study, the PCR-RFLP method was successfully carried out to accurately detect the polymorphisms of the $\mathrm{MYH}_{3}$ gene.

At the SNP1-RSaI locus, digestion of the $435 \mathrm{bp}$ PCR fragment of $\mathrm{MYH}_{3}$ exon 5 with $\mathrm{RSaI}$ resulted in fragment lengths of 228, 207, 150 and 78 bp for genotype CT; 228, 207, 150 and $78 \mathrm{bp}$ for genotype TT and 228 and $207 \mathrm{bp}$ for genotype CC (see Fig. 1). The frequencies of genotype and allele were calculated in the Qinchuan bovine population (Table 2). The frequency of allele $\mathrm{T}$ was dominant in the Qinchuan cattles and CT genotype was more frequent than other genotypes. The genotypic frequencies of SNP1$R S a \mathrm{I}$ locus in Qinchuan cattle population agreed with Hardy-Weinberg disequilibrium $\quad(0.01<P<0.05)$ (Table 3).

At the SNP2-BstXI locus, digestion of the 435 bp PCR fragment with $B$ st XI resulted in fragment lengths of $435 \mathrm{bp}$ for genotype TT; 435, 339 and $96 \mathrm{bp}$ for genotype TC and 339 and 96 bp for genotype CC (see Fig. 2). The frequency of allele $\mathrm{C}$ was dominant in the Qinchuan breeds and TC genotype was more frequent than other genotypes. The genotypic frequencies of SNP2-BstXI locus in Qinchuan cattle population agreed with Hardy-Weinberg equilibrium $(P>0.05)$ (Table 3).

At the SNP3-PVUII locus, digestion of the 447 bp PCR fragment with $P V U I I$ resulted in fragment lengths of 447 bp for genotype GG; 447, 225 and 222 bp for genotype GC and 225 and 222 bp for genotype CC (see Fig. 3). The frequency of allele $\mathrm{C}$ was dominant in the Qinchuan breeds and GC genotype was more frequent than other genotypes. The genotypic frequencies of SNP3-PVUII locus in Qinchuan cattle population agreed with HardyWeinberg disequilibrium $(P<0.01)$ (Table 3$)$. 
Table 3 Genotypic and allelic frequencies (\%), value of $\chi_{2}^{2}$ test and diversity parameter of bovine $\mathrm{MYH}_{3}$ gene

\begin{tabular}{|c|c|c|c|c|c|c|c|c|c|c|}
\hline SNPs & Genotype & Number & GF & Allele & $\mathrm{AF}$ & $\chi^{2}(\mathrm{HWE})^{\mathrm{e}}$ & $\mathrm{He}$ & $H_{O}$ & $\mathrm{Ne}$ & $P I C$ \\
\hline \multirow[t]{3}{*}{ SNP1 } & $\mathrm{CC}$ & 51 & 0.1397 & $\mathrm{C}$ & 0.4205 & & & & & \\
\hline & $\mathrm{CT}$ & 205 & 0.5616 & $\mathrm{~T}$ & 0.5795 & 8.4758 & 0.4874 & 0.5126 & 1.9508 & 0.3686 \\
\hline & TT & 109 & 0.2986 & & & & & & & \\
\hline \multirow[t]{3}{*}{ SNP2 } & TT & 56 & 0.1534 & $\mathrm{~T}$ & 0.4233 & & & & & \\
\hline & $\mathrm{TC}$ & 197 & 0.5397 & $\mathrm{C}$ & 0.5767 & 4.0605 & 0.4882 & 0.5118 & 1.9539 & 0.3690 \\
\hline & $\mathrm{CC}$ & 112 & 0.3068 & & & & & & & \\
\hline \multirow[t]{3}{*}{ SNP3 } & GG & 43 & 0.1178 & G & 0.4384 & & & & & \\
\hline & GC & 234 & 0.6411 & $\mathrm{C}$ & 0.5616 & 33.2854 & 0.4924 & 0.5076 & 1.9701 & 0.3712 \\
\hline & $\mathrm{CC}$ & 88 & 0.2411 & & & & & & & \\
\hline \multirow[t]{3}{*}{ SNP4 } & CC & 39 & 0.1068 & C & 0.4068 & & & & & \\
\hline & CT & 219 & 0.6000 & $\mathrm{~T}$ & 0.5932 & 21.5790 & 0.4826 & 0.5174 & 1.9327 & 0.3661 \\
\hline & $\mathrm{TT}$ & 107 & 0.2932 & & & & & & & \\
\hline \multirow[t]{3}{*}{ SNP5 } & $\mathrm{CC}$ & 46 & 0.1260 & $\mathrm{C}$ & 0.4123 & & & & & \\
\hline & CT & 209 & 0.5726 & $\mathrm{~T}$ & 0.5877 & 12.0281 & 0.4846 & 0.5154 & 1.9402 & 0.3672 \\
\hline & TT & 110 & 0.3014 & & & & & & & \\
\hline
\end{tabular}

Note: SNPs: single nucleotide polymorphisms; SNP1 = C1878T; SNP2 = T2010C; SNP3 = G3746C; SNP4 = C7294T; SNP5 = C7315T Number: genotype number

GF: genotypic frequency; AF: allelic frequency; $\chi^{2}$ (HWE): Hardy-Weinberg equilibrium $\chi^{2}$ value; He: gene heterozygosity; Ho: gene homozygosity; Ne: effective allele numbers; PIC: polymorphism information content

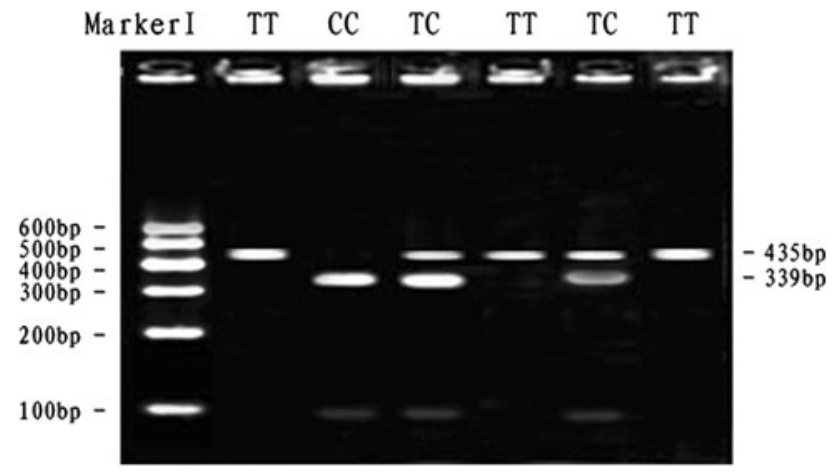

Fig. 2 The $3 \%$ agarose gels electrophoretic patterns of the $\mathrm{MYH}_{3}$ gene in bovine. $\mathrm{M}=$ DNA molecular weight marker is Marker I; T2010C genotype: $\mathrm{TT}=435 \mathrm{bp}, \quad \mathrm{TC}=435+339+96 \mathrm{bp}$, $\mathrm{CC}=339+96 \mathrm{bp}$; It is difficult to see the $96 \mathrm{bp}$ DNA fragment on $3 \%$ agarose gel

At the SNP4-RSaI locus, digestion of the 532 bp PCR fragment with $R S a \mathrm{I}$ resulted in fragment lengths of $532 \mathrm{bp}$ for genotype CC; 532, 364 and 168 bp for genotype CT and 364 and $168 \mathrm{bp}$ for genotype TT (see Fig. 4). The frequency of allele $\mathrm{T}$ was dominant in the Qinchuan breeds and CT genotype was more frequent than other genotypes. The genotypic frequencies of SNP4-RSaI locus in Qinchuan cattle population agreed with Hardy-Weinberg disequilibrium $(P<0.01)$ (Table 3$)$.

At the SNP5-TaqI locus, digestion of the 433 bp PCR fragment with TaqI resulted in fragment lengths of $433 \mathrm{bp}$ for genotype CC; 433, 243 and 190 bp for genotype CT

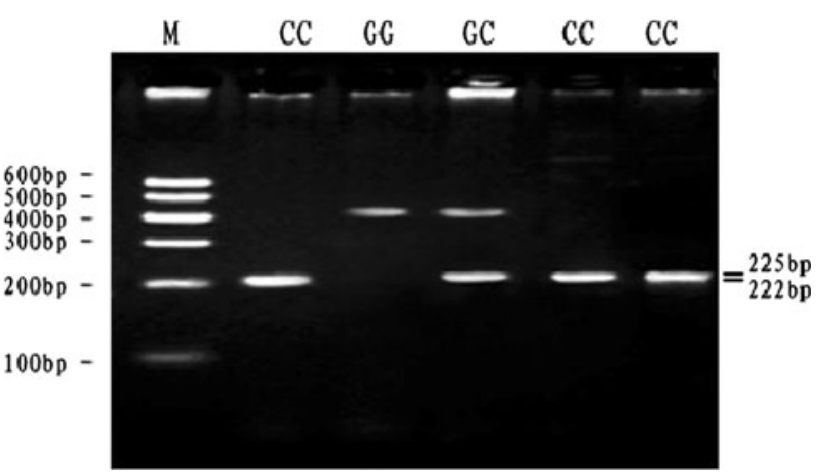

Fig. 3 The $2.5 \%$ agarose gels electrophoretic patterns of the $\mathrm{MYH}_{3}$ gene in bovine. $\mathrm{M}=\mathrm{DNA}$ molecular weight marker is Marker I; G3746C genotype: $\mathrm{GG}=447 \mathrm{bp}, \quad \mathrm{GC}=447+225+222 \mathrm{bp}$, $\mathrm{CC}=225+222 \mathrm{bp}$; It is difficult to see the $222 \mathrm{bp}$ and $225 \mathrm{bp}$ DNA fragment on $2.5 \%$ agarose gel

and 243 and $190 \mathrm{bp}$ for genotype TT (see Fig. 5). The frequency of allele $\mathrm{T}$ was dominant in the Qinchuan and CT genotype was more frequent than other genotypes. The genotypic frequencies of SNP5-TaqI locus in Qinchuan cattle population agreed with Hardy-Weinberg disequilibrium $(P<0.01)$ (Table 3$)$.

Analysis of polymorphism of the $\mathrm{MYH}_{3}$ in Qinchuan cattle population

The means and standard deviations (SD) for traits were analyzed in this study shown in Table 4 . The allelic and 


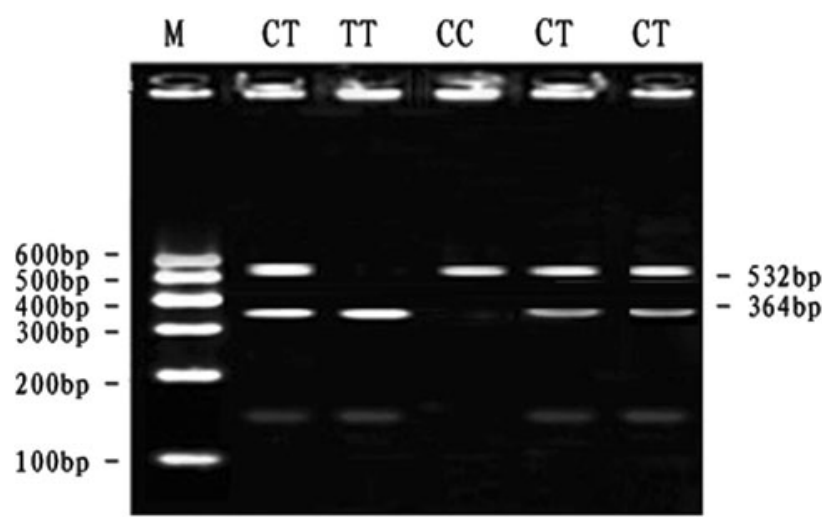

Fig. 4 The $2.5 \%$ agarose gels electrophoretic patterns of the $\mathrm{MYH}_{3}$ gene in bovine. $\mathrm{M}=$ DNA molecular weight marker is Marker I; C7294T genotype: $\mathrm{CC}=532 \mathrm{bp}, \quad \mathrm{CT}=532+364+168 \mathrm{bp}$, $\mathrm{TT}=364+168 \mathrm{bp}$; It is difficult to see the $168 \mathrm{bp}$ DNA fragment on $2.5 \%$ agarose gel

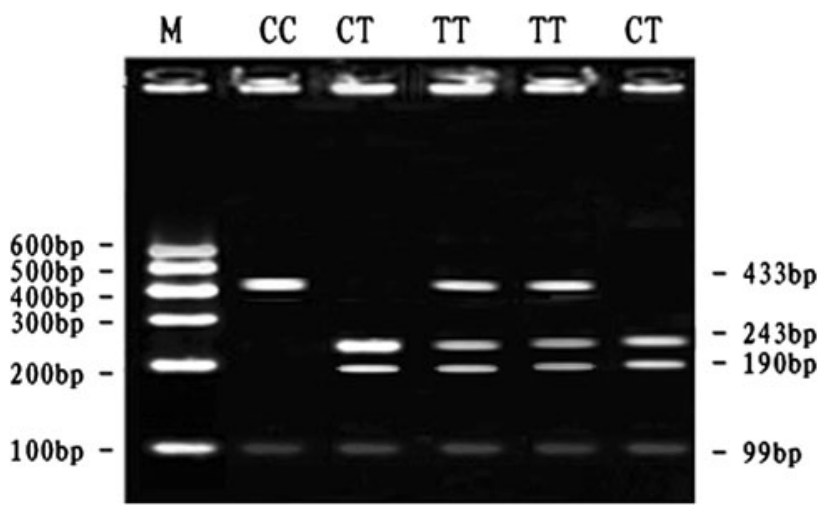

Fig. 5 The $3 \%$ agarose gels electrophoretic patterns of the $\mathrm{MYH}_{3}$ gene in bovine. $\mathrm{M}=$ DNA molecular weight marker is MarkerI; C7315T genotype: $\mathrm{CC}=433+99 \mathrm{bp}, \mathrm{CT}=243+190+99 \mathrm{bp}$, $\mathrm{TT}=433+243+190+99 \mathrm{bp}$

genotypic frequencies, genetic diversity parameters $(\mathrm{Ho}$, $\mathrm{He}, \mathrm{Ne}$ and $\mathrm{PIC}$ ) of the five SNPs were shown in Table 3. According to Table 3, only one loci of Qinchuan cattle was in Hardy-Weinberg equilibrium $(P>0.05)$. It showed that the Qinchuan cattle breed was in a dynamic disequilibrium in artificial selection, migration and genetic drift function. The maximum and minimum PIC values were 0.3661 and 0.3690 . According to the genetic diversity classification of PIC (PIC value $<0.25$, low polymorphism; $0.25<$ PIC value $<0.5$, intermediate polymorphism and $P I C$ value $>0.5$, high polymorphism), at the five SNPs, the result reflected that an intermediate genetic diversity of Qinchuan bovine $\mathrm{MYH}_{3}$ gene in the population analyzed.
Table 4 Means and standard deviations (SD) for traits

\begin{tabular}{lrr}
\hline Traits & Mean & \multicolumn{1}{c}{ SD } \\
\hline Body height $(\mathrm{cm})$ & 140.22 & 4.26 \\
Withers length $(\mathrm{cm})$ & 150.71 & 6.14 \\
Hip width $(\mathrm{cm})$ & 48.00 & 3.66 \\
Slaughter weight $(\mathrm{kg})$ & 497.96 & 63.67 \\
Carcass weight $(\mathrm{kg})$ & 268.87 & 36.99 \\
\hline
\end{tabular}

Table 5 The estimated values of linkage equilibrium analysis between 5 mutation sites within $\mathrm{MYH}_{3}$ gene of studied population

\begin{tabular}{llllll}
\hline SNPs & 1 & 2 & 3 & 4 & 5 \\
\hline 1 & & $\mathrm{D}^{\prime}=0.077$ & $\mathrm{D}^{\prime}=0.080$ & $\mathrm{D}^{\prime}=0.026$ & $\mathrm{D}^{\prime}=0.011$ \\
2 & $r^{2}=0.003$ & & $\mathrm{D}^{\prime}=0.087$ & $\mathrm{D}^{\prime}=0.080$ & $\mathrm{D}^{\prime}=0.110$ \\
3 & $r^{2}=0.002$ & $r^{2}=0.003$ & & $\mathrm{D}^{\prime}=0.439$ & $\mathrm{D}^{\prime}=0.580$ \\
4 & $r^{2}=0.001$ & $r^{2}=0.004$ & $r^{2}=0.110$ & & $\mathrm{D}^{\prime}=0.422$ \\
5 & $r^{2}=0.000$ & $r^{2}=0.005$ & $r^{2}=0.292$ & $r^{2}=0.117$ & \\
\hline SNPs & single nucleotide polymorphisms; & $1=\mathrm{C} 1878 \mathrm{~T} ;$ & $2=\mathrm{T} 2010 \mathrm{C} ;$ \\
$3=\mathrm{G} 3746 \mathrm{C} ;$ 4 = C7294T; 5 = C7315T &
\end{tabular}

Linkage disequilibrium and haplotype analysis of the $\mathrm{MYH}_{3}$ in Qinchuan cattle population

Linkage disequilibrium and haplotype analysis of the $\mathrm{MYH}_{3}$ gene in Qinchuan cattle population were shown in Tables 5 and 6 . The linkage disequilibrium between the five SNPs in the population was estimated, which indicated that the $D^{\prime}$ values ranged from 0.011 to 0.58 ; the $r^{2}$ values were from 0.000 to 0.292 . Moreover, SNP1 and SNP2SNP5 had little linkage equilibrium $\left(D^{\prime}<0.07\right.$ and $\left.r^{2}<0.003\right)$. SNP2 and SNP3-SNP5 had little linkage equilibrium $\left(D^{\prime}<0.08\right.$ and $\left.r^{2}<0.003\right)$.

The haplotype analysis showed that eight different haplotypes were identified among the three SNPs. Three major haplotypes accounting for $75.2 \%$ of the alleles were obtained as follows, haplotype 2: -CCT- $(14.9 \%)$, haplotype 4, -CTT- (39.3\%) and haplotype 5, -GCC$(21.0 \%)$.

Association analysis of single markers and combined genotypes

The results of the association analyses between five mutations in $\mathrm{MYH}_{3}$ and growth and carcass traits were shown in Table 7. Growth and carcass traits were associated by the analysis of Qinchuan cattle at $30 \pm 2$ months old. According to Table 7, at locus C1878T, the animals with the CT genotype had greater withers height and heavier slaughter weight than those with the TT genotype 
$(P<0.05)$. At locus T2010C, the TT genotype was better than the TC and CC genotypes, and the animals with the TT genotype had greater withers height than those with the CC genotype $(P<0.05)$, the animals with the TT genotype had heavier slaughter weight than those with the TC and CC genotypes $(P<0.05)$. At locus $\mathrm{G} 3746 \mathrm{C}$, the animals with the GG genotype had greater body length and withers

Table 6 Haplotype and haplotype frequency within studied population of 3 SNPs in bovine $\mathrm{MYH}_{3}$ gene

\begin{tabular}{llllll}
\hline Haplotype & SNPs & & & $\begin{array}{l}\text { Frequency } \\
\text { in } \\
\text { population }\end{array}$ & $\begin{array}{l}\text { Cumulative } \\
\text { frequency }\end{array}$ \\
\hline & & & \multicolumn{4}{l}{} \\
Hap 1 & G3746C & C $7294 T$ & C7315T & \\
Hap 2 & C & C & C & 0.080 & 0.080 \\
Hap 3 & C & T & T & 0.149 & 0.229 \\
Hap 4 & C & T & T & 0.046 & 0.275 \\
Hap 5 & G & C & C & 0.393 & 0.668 \\
Hap 6 & G & C & T & 0.038 & 0.878 \\
Hap 7 & G & T & C & 0.034 & 0.916 \\
Hap 8 & G & T & T & 0.050 & 1.000 \\
\hline
\end{tabular}

height than those with the GC and $\mathrm{CC}$ genotypes $(P<0.05)$, and GG genotype had greater hip width than those with GC genotype $(P<0.05)$. At locus C7315T, the animals with the $\mathrm{CC}$ genotype had heavier slaughter weight than those with $\mathrm{CT}$ genotype $(P<0.05)$. The rest of the records of growth and carcass traits had no significant association $(P>0.05)$.S

The combined genotypes association results for SNP3, SNP4 and SNP5 were shown in Table 8. The associated analysis suggested that no significant differences were detected between the combined genotypes of three SNPs and growth and carcass traits in Qinchuan cattle $(P>0.05)$.

\section{Discussion}

In previous studies, the $\mathrm{MYH}_{3}$ gene is the majority myosin isoform in embryonic and neonatal muscle fibers and its expression declines after birth to become undetectable around 3 weeks postnatal [45]. $\mathrm{MYH}_{3}$ expression demonstrates in the early looping heart, and subsequently throughout the myocardium of the outflow tract, and at lower levels to the ventricular chamber [38]. Knockdown of $\mathrm{MYH}_{3}$ in the chick resulted in abnormal atrial septal

Table 7 Association of SNPs with growth and carcass traits

\begin{tabular}{|c|c|c|c|c|c|c|c|}
\hline Locus & Genotype & $\mathrm{N}$ & $\begin{array}{l}\text { Body length }(\mathrm{cm}) \\
(\text { mean } \pm S E)\end{array}$ & $\begin{array}{l}\text { Withers height }(\mathrm{cm}) \\
(\text { mean } \pm \mathrm{SE})\end{array}$ & $\begin{array}{l}\text { Hip width }(\mathrm{cm}) \\
(\text { mean } \pm \mathrm{SE})\end{array}$ & $\begin{array}{l}\text { Slaughter weight }(\mathrm{kg}) \\
(\text { mean } \pm \mathrm{SE})\end{array}$ & $\begin{array}{l}\text { Carcass weight }(\mathrm{kg}) \\
(\text { mean } \pm \mathrm{SE})\end{array}$ \\
\hline \multirow[t]{4}{*}{$\mathrm{C} 1878 \mathrm{~T}$} & $\mathrm{CC}$ & 51 & $140.681 \pm 0.882$ & $151.306 \pm 0.991^{\mathrm{ab}}$ & $47.292 \pm 0.622$ & $497.056 \pm 10.171^{\mathrm{ab}}$ & $265.425 \pm 5.656$ \\
\hline & $\mathrm{CT}$ & 205 & $140.382 \pm 0.524$ & $150.382 \pm 0.589^{\mathrm{b}}$ & $46.750 \pm 0.370$ & $495.824 \pm 6.043^{\mathrm{b}}$ & $266.104 \pm 3.360$ \\
\hline & TT & 109 & $140.753 \pm 0.603$ & $152.506 \pm 0.678^{\mathrm{a}}$ & $47.299 \pm 0.425$ & $505.623 \pm 6.955^{\mathrm{a}}$ & $273.209 \pm 3.868$ \\
\hline & $\mathrm{P}$ & & 0.889 & 0.063 & 0.564 & 0.049 & 0.321 \\
\hline \multirow[t]{4}{*}{ T2010C } & $\mathrm{TT}$ & 56 & $140.568 \pm 0.777$ & $149.676 \pm 0.947^{\mathrm{b}}$ & $46.676 \pm 0.573$ & $487.243 \pm 9.266$ & $258.881 \pm 5.260^{\mathrm{b}}$ \\
\hline & $\mathrm{TC}$ & 197 & $140.055 \pm 0.637$ & $150.855 \pm 0.777^{\mathrm{ab}}$ & $47.491 \pm 0.470$ & $497.036 \pm 7.600$ & $268.102 \pm 4.314^{\mathrm{a}}$ \\
\hline & $\mathrm{CC}$ & 112 & $141.206 \pm 0.811$ & $152.735 \pm 0.988^{\mathrm{a}}$ & $46.941 \pm 0.598$ & $509.706 \pm 9.666$ & $265.806 \pm 5.487^{\mathrm{a}}$ \\
\hline & $\mathrm{P}$ & & 0.536 & 0.043 & 0.521 & 0.248 & 0.032 \\
\hline \multirow[t]{4}{*}{ G3746C } & GG & 43 & $138.629 \pm 0.940^{\mathrm{b}}$ & $148.742 \pm 1.065^{\mathrm{b}}$ & $45.758 \pm 0.666^{\mathrm{b}}$ & $484.290 \pm 10.908$ & $264.461 \pm 6.115$ \\
\hline & $\mathrm{GC}$ & 234 & $140.964 \pm 0.575^{\mathrm{a}}$ & $151.892 \pm 0.651^{\mathrm{a}}$ & $47.301 \pm 0.407^{\mathrm{a}}$ & $507.000 \pm 6.667$ & $271.022 \pm 3.737$ \\
\hline & $\mathrm{CC}$ & 88 & $140.832 \pm 0.521^{\mathrm{a}}$ & $151.594 \pm 0.590^{\mathrm{a}}$ & $47.213 \pm 0.369^{\mathrm{ab}}$ & $498.089 \pm 6.043$ & $267.742 \pm 3.388$ \\
\hline & $\mathrm{P}$ & & 0.085 & 0.035 & 0.117 & 0.198 & 0.625 \\
\hline \multirow[t]{4}{*}{ C7294T } & $\mathrm{CC}$ & 39 & $140.353 \pm 0.680$ & $151.138 \pm 0.782$ & $46.914 \pm 0.494$ & $492.552 \pm 7.986$ & $266.414 \pm 4.518$ \\
\hline & $\mathrm{CT}$ & 219 & $140.146 \pm 0.572$ & $150.524 \pm 0.658$ & $47.067 \pm 0.416$ & $500.061 \pm 6.716$ & $271.487 \pm 3.800$ \\
\hline & $\mathrm{TT}$ & 107 & $141.308 \pm 0.643$ & $152.123 \pm 0.739$ & $47.146 \pm 0.467$ & $501.539 \pm 7.544$ & $267.275 \pm 4.268$ \\
\hline & $\mathrm{P}$ & & 0.376 & 0.272 & 0.942 & 0.681 & 0.637 \\
\hline \multirow[t]{4}{*}{$\mathrm{C} 7315 \mathrm{~T}$} & $\mathrm{CC}$ & 46 & $140.283 \pm 0.964$ & $149.700 \pm 1.094$ & $46.467 \pm 0.681$ & $485.100 \pm 11.141^{\mathrm{b}}$ & $268.123 \pm 6.243$ \\
\hline & $\mathrm{CT}$ & 209 & $140.112 \pm 0.533$ & $151.837 \pm 0.605$ & $47.026 \pm 0.377$ & $504.102 \pm 6.164^{\mathrm{a}}$ & $268.125 \pm 3.454$ \\
\hline & TT & 110 & $141.14 \pm 0.569$ & $151.198 \pm 0.646$ & $47.192 \pm 0.402$ & $499.372 \pm 6.580^{\mathrm{ab}}$ & $269.176 \pm 3.687$ \\
\hline & $\mathrm{P}$ & & 0.404 & 0.231 & 0.657 & 0.030 & 0.976 \\
\hline
\end{tabular}

Note: Values with different superscripts within the same column differ significantly at $P<0.05(\mathrm{a}, \mathrm{b})$

$S E$ standard error 
Table 8 Associations between combined genotypes of three SNPs and growth and carcass traits in Qinchuan cattle $(\mathrm{N}=365)$ : Mean \pm SE

\begin{tabular}{|c|c|c|c|c|c|c|}
\hline $\begin{array}{l}\text { Genotype of } \\
\text { combination (19) }\end{array}$ & $\begin{array}{l}\text { Number of } \\
\text { combination }\end{array}$ & $\begin{array}{l}\text { Body length }(\mathrm{cm}) \\
(\text { mean } \pm \mathrm{SE})\end{array}$ & $\begin{array}{l}\text { Withers height }(\mathrm{cm}) \\
(\text { mean } \pm \mathrm{SE})\end{array}$ & $\begin{array}{l}\text { Hip width }(\mathrm{cm}) \\
\text { (mean } \pm \mathrm{SE})\end{array}$ & $\begin{array}{l}\text { Slaughter weight } \\
(\mathrm{kg})(\text { mean } \pm \mathrm{SE})\end{array}$ & $\begin{array}{l}\text { Carcass weight }(\mathrm{kg}) \\
(\text { mean } \pm \mathrm{SE})\end{array}$ \\
\hline $1 \mathrm{CCCCCC}$ & 7 & $139.33 \pm 3.09$ & $150.67 \pm 3.49$ & $48.33 \pm 2.18$ & $467.33 \pm 36.02$ & $283.73 \pm 19.78$ \\
\hline 2 СССССТ & 15 & $140.29 \pm 2.03$ & $152.29 \pm 2.29$ & $46.43 \pm 1.43$ & $515.14 \pm 23.58$ & $259.40 \pm 12.95$ \\
\hline 3 ССССТТ & 8 & $137.50 \pm 3.79$ & $153.00 \pm 4.28$ & $45.50 \pm 2.68$ & $496.00 \pm 44.11$ & $264.10 \pm 24.22$ \\
\hline 4 СССТСС & 8 & $145.00 \pm 3.79$ & $152.50 \pm 4.28$ & $47.00 \pm 2.68$ & $524.00 \pm 44.11$ & $255.90 \pm 24.22$ \\
\hline 5 СССТСТ & 25 & $140.13 \pm 1.38$ & $151.40 \pm 1.56$ & $47.57 \pm 0.98$ & $490.80 \pm 16.11$ & $263.33 \pm 8.85$ \\
\hline 6 СССТТТ & 40 & $141.00 \pm 1.05$ & $150.81 \pm 1.19$ & $46.73 \pm 0.74$ & $498.31 \pm 12.23$ & $271.83 \pm 6.72$ \\
\hline 7 ССТТСС & 6 & $142.00 \pm 3.79$ & $152.00 \pm 4.28$ & $47.50 \pm 2.68$ & $503.50 \pm 44.11$ & $285.10 \pm 24.22$ \\
\hline 8 ССТТСТ & 16 & $139.67 \pm 1.79$ & $153.33 \pm 2.02$ & $46.90 \pm 1.26$ & $490.11 \pm 20.79$ & $270.44 \pm 11.42$ \\
\hline 9 ССТТТТ & 50 & $141.30 \pm 0.88$ & $151.68 \pm 0.99$ & $47.65 \pm 0.66$ & $501.70 \pm 10.26$ & $266.39 \pm 5.63$ \\
\hline 10 GCCCCC & 10 & $140.50 \pm 2.68$ & $147.75 \pm 3.02$ & $45.75 \pm 1.89$ & $463.50 \pm 31.19$ & $264.75 \pm 17.13$ \\
\hline 11 GCCCCT & 28 & $141.80 \pm 1.20$ & $153.95 \pm 1.35$ & $48.45 \pm 0.85$ & $503.25 \pm 13.95$ & $264.54 \pm 7.66$ \\
\hline 12 GCCTCT & 40 & $140.07 \pm 1.03$ & $151.78 \pm 1.16$ & $47.37 \pm 0.73$ & $520.41 \pm 12.01$ & $279.10 \pm 6.59$ \\
\hline 13 GCCTTT & 22 & $140.73 \pm 1.62$ & $150.09 \pm 1.82$ & $47.00 \pm 1.14$ & $485.82 \pm 18.81$ & $265.65 \pm 10.33$ \\
\hline 14 GCTTCT & 15 & $141.40 \pm 1.70$ & $152.40 \pm 1.91$ & $45.80 \pm 1.20$ & $512.60 \pm 19.73$ & $263.54 \pm 10.83$ \\
\hline 15 GCTTTT & 11 & $141.88 \pm 1.90$ & $150.75 \pm 2.14$ & $47.38 \pm 1.34$ & $511.25 \pm 22.06$ & $266.58 \pm 12.11$ \\
\hline 16 GGCCCC & 25 & $139.79 \pm 1.30$ & $149.18 \pm 1.47$ & $46.53 \pm 0.91$ & $483.76 \pm 15.13$ & $265.93 \pm 8.31$ \\
\hline 17 GGCCCT & 9 & $136.40 \pm 2.40$ & $148.20 \pm 2.71$ & $44.00 \pm 1.69$ & $479.20 \pm 27.90$ & $258.28 \pm 15.32$ \\
\hline 18 GGCTCT & 10 & $136.67 \pm 2.19$ & $146.00 \pm 2.47$ & $45.67 \pm 1.54$ & $480.83 \pm 25.47$ & $264.87 \pm 13.99$ \\
\hline 19 GGTTCC & 5 & $139.00 \pm 3.79$ & $151.50 \pm 4.28$ & $43.00 \pm 2.68$ & $509.00 \pm 44.11$ & $265.35 \pm 24.22$ \\
\hline $\begin{array}{l}\text { Significance } \\
(P \text { value })\end{array}$ & & 0.83 & 0.59 & 0.75 & 0.93 & 0.99 \\
\hline
\end{tabular}

$S E$ standard error

development, similar to that seen upon $\alpha-M Y H$ knockdown [46, 47]. These results support the idea that $\mathrm{MYH}_{3}$ is a fundamental process in skeletal muscle and heart development. Another study finds that myosin myopathies have evolved as a new group of muscle diseases caused by mutations in skeletal muscle myosin heavy-chain genes [48].

Up to now, there are few polymorphisms detected in the $\mathrm{MYH}_{3}$ gene, it may be related to meat quality traits. We choosed it as a candidate gene to identify its SNPs and analyze the associations between the polymorphism and growth and carcass traits in the Qinchuan cattle population, which would lay the foundation for the study on the function of $\mathrm{MYH}_{3}$ gene in the cattle breed.

The allelic and genotypic frequencies, $\mathrm{PIC}, \mathrm{He}, \mathrm{Ne}$ and $\chi 2$ values for SNPs showed considerable variability in Qinchuan cattle, the allelic frequency of the $\mathrm{T}$ alleles in five loci were up to 0.42 and $\mathrm{C}$ alleles in five loci were up to 0.40. PIC, He and Ne of SNP3 were higher than other four SNPs, showed the high polymorphism, high genetic variability, high ability to maintain allelic stability during selection or mutation, so SNP3 was likely to be useful in breeding programs for Qinchuan cattle. Chisquared tests of SNP1, SNP3, SNP4 and SNP5 did not agreed with Hardy-Weinberg equilibrium $(0.01<$
$P<0.05, \quad P<0.01, \quad P<0.01$ and $P<0.01$, respectively), while SNP2 met with the Hardy-Weinberg equilibrium $(P>0.05)$.

In this study, we first reported the novel five SNPs in bovine $\mathrm{MYH}_{3}$ gene, and its association analysis with the growth and carcass traits in bovine. The genotypes at locus C1878T had a significant effect on slaughter weight. The genotypes at locus T2010C had a significant effect on withers height and carcass weight. The genotypes at locus G3746C had a significant effect on withers height. The genotypes at locus $\mathrm{C} 7315 \mathrm{~T}$ had a significant effect on slaughter weight. Based on these study, the individuals with better performance with the CT genotype at locus C1878T and TT genotypes at locus T2010C and GG genotypes at locus G3746C and CC genotypes at locus C7315T could be used for the development of new breeds of beef cattle in China, and these four locus could be used as remarkable molecular markers for better performance in the bovine industry.

The result of haplotype analysis of three major loci showed that eight different haplotypes were identified which get nineteen combined haplotypes, and all nineteen combined genotypes were found in this study animal DNA samples, four major combined haplotypes accounting for $51.9 \%$ of the haplotypes were obtained as follows, 
CССТTT: $(12.3 \%)$, CCTTTT: (17.5\%), GCСТCT: (9.4\%), GCCCCT: (12.7\%). But the associated analysis suggested that no significant differences were detected between the combined genotypes of three SNPs and growth and carcass traits in Qinchuan cattle $(P>0.05)$. So this study indicated that combined haplotypes did not increase growth or carcass traits of Qinchuan cattle.

In our study, three mutations in the bovine $\mathrm{MYH}_{3}$ gene were found in the exon region, polymorphisms in these regions could alter gene expression. The SNP g. $+7294 \mathrm{C}>\mathrm{T}$ was a missense mutation Arg2432Cys. It is possible to change the important physiological function in secondary and tertiary configuration of $\mathrm{MYH}_{3}$ protein as well as affect the biological function of protein, and it needs to study further. Our study was the first report of five novel SNPs in the bovine $\mathrm{MYH}_{3}$ gene, and we analyzed their association with growth and carcass traits in Qinchuan cattle. The results showed that some genotypes had a significant effect on the growth and carcass traits. Therefore, these mutations of $\mathrm{MYH}_{3}$ gene might positively influence the growth and carcass traits in Qinchuan population. In conclusion, this study will be contributed to geneticists and breeders as a molecular marker for better performance in the bovine industry. While the further research is still needed to clarify the role on the genetic variants of the $\mathrm{MYH}_{3}$ gene, and to analyze the mRNA expression levels of the $\mathrm{MYH}_{3}$ gene. Hence, would be a candidate gene worthy of further investigation.

Acknowledgments Research supported by the 12th "Five-Year" National Science and Technology Key Project (No. 2011AA100307), the National "863" Program of China (No. 2008AA101010), "13115" Sci-Tech Innovation Program of Shaanxi Province (No. 2008ZDKG-11).

Open Access This article is distributed under the terms of the Creative Commons Attribution License which permits any use, distribution, and reproduction in any medium, provided the original author(s) and the source are credited.

\section{References}

1. Diagana TT, North DL, Jabet C, Fiszman MY, Takeda S, Whalen RG (1997) The transcriptional activity of a muscle-specific promoter depends critically on the structure of the TATA element and its binding protein. J Mol Biol 265(5):480-493

2. Lakich MM, Diagana TT, North DL, Whalen RG (1998) MEF-2 and Oct-1 bind to two homologous promoter sequence elements and participate in the expression of a skeletal muscle-specific gene. J Biol Chem 273(24):15217-15226

3. Swoap SJ (1998) In vivo analysis of the myosin heavy chain IIB promoter region. Am J Physiol 274(3Pt1):C681-C687

4. Takeda S, North DL, Lakich MM, Russell SD, Whalen RG (1992) A possible regulatory role for conserved promoter motifs in an adult-specific muscle myosin gene from mouse. J Biol Chem 267(24): 16957-16967

5. Takeda S, North DL, Diagana T, Miyagoe Y, Lakich MM, Whalen RG (1995) Myogenic regulatory factors can activate TATA-containing promoter elements via an E-box independent mechanism. J Biol Chem 270(26):15664-15670

6. Wheeler MT, Snyder EC, Patterson MN, Swoap SJ (1999) An E-box within the MHC IIB gene is bound by MyoD and is required for gene expression in fast muscle. Am $\mathrm{J}$ Physiol 276(5Pt1):C1069-C1078

7. Lieber RL, Bodine SC, Burkholder TJ, Pierotti DJ, Ryan AF (1993) Cloning and in situ hybridization of type 2A and 2B rat skeletal muscle myosin tail region: implications for filament assembly. Biochem Biophys Res Commun 197(3):1312-1318

8. DeNardi C, Ausoni S, Moretti P, Gorza L, Velleca M, Buckingham M, Schiaffino S (1993) Type 2X-myosin heavy chain is coded by a muscle fiber type-specific and developmentally regulated gene. J Cell Biol 123(4):823-835

9. Wieczorek DF, Periasamy M, Butler-Browne GS, Whalen RG, Nadal-Ginard B (1985) Co-expression of multiple myosin heavy chain genes, in addition to a tissue-specific one, in extraocular musculature. J Cell Biol 101(2):618-629

10. Strehler EE, Strehler-Page MA, Perriard JC, Periasamy M, Nadal-Ginard B (1986) Complete nucleotide and encoded amino acid sequence of a mammalian myosin heavy chain gene. Evidence against intron-dependent evolution of the rod. J Mol Biol 190(3):291-317

11. Periasamy M, Wieczorek DF, Nadal-Ginard B (1984) Characterization of a developmentally regulated perinatal myosin heavychain gene expressed in skeletal muscle. J Biol Chem 259(21): 13573-13578

12. Weiss A, McDonough D, Wertman B, Acakpo-Satchivi L, Montgomery K, Kucherlapati R, Leinwand L, Krauter K (1999) Organization of human and mouse skeletal myosin heavy chain gene clusters is highly conserved. Proc Natl Acad Sci USA 96(6): 2958-2963

13. Lyons GE, Ontell M, Cox R, Sassoon D, Buckingham M (1990) The expression of myosin genes in developing skeletal muscle in the mouse embryo. J Cell Biol 111(4):1465-1476

14. Weydert A, Daubas P, Caravatti M, Minty A, Bugaisky G, Cohen A, Robert B, Buckingham M (1983) Sequential accumulation of mRNAs encoding different myosin heavy chain isoforms during skeletal muscle development in vivo detected with a recombinant plasmid identified as coding for an adult fast myosin heavy chain from mouse skeletal muscle. J Biol Chem 258(22):13867-13874

15. Whalen RG, Sell SM, Butler-Browne GS, Schwartz K, Bouveret P, Pinset-Harstom I (1981) Three myosin heavy-chain isozymes appear sequentially in rat muscle development. Nature 292(5826): 805-809

16. Rubinstein NA, Kelly AM (1981) Development of muscle fiber specialization in the rat hindlimb. J Cell Biol 90(1):128-144

17. Hundley AF, Yuan L, Visco AG (2006) Skeletal muscle heavychain polypeptide 3 and myosin binding protein $\mathrm{H}$ in the pubococcygeus muscle in patients with and without pelvic organ prolapse. Am J Obstet Gynecol 194(5):1404-1410

18. Zhang YY, Zan LS, Wang HB, Qing L, Wu KX, Quan SA, Li CQ, Zhong X, Wang CJ (2011) Differentially expressed genes in skeletal muscle tissues from castrated Qinchuan cattle males compared with those from intact males. Livest Sci 135(1):76-83

19. Bober E, Buchberger-Seidl A, Braun T, Singh S, Goedde HW, Arnold HH (1990) Identification of three developmentally controlled isoforms of human myosin heavy chains. Eur J Biochem 189(1):55-65

20. di Maso NA, Caiozzo VJ, Baldwin KM (2000) Single-fiber myosin heavy chain polymorphism during postnatal 
development: modulation by hypothyroidism. Am J Physiol Regul Integr Comp Physiol 278(4):R1099-R1106

21. Staron RS, Pette D (1987) The multiplicity of combinations of myosin light chains and heavy chains in histochemically typed single fibres. Rabbit tibialis anterior muscle. Biochem J 243(3):695-699

22. Termin A, Staron RS, Pette D (1989) Changes in myosin heavy chain isoforms during chronic low-frequency stimulation of rat fast hindlimb muscles. A single-fiber study. Eur J Biochem 186(3):749-754

23. Termin A, Staron RS, Pette D (1989) Myosin heavy chain isoforms in histochemically defined fiber types of rat muscle. Histochemistry $92(6): 453-457$

24. Eller M, Stedman HH, Sylvester JE, Fertels SH, Wu QL, Raychowdhury MK, Rubinstein NA, Kelly AM, Sarkar S (1989) Human embryonic myosin heavy chain cDNA. Interspecies sequence conservation of the myosin rod, chromosomal locus and isoform specific transcription of the gene. FEBS Lett 256(1-2): $21-28$

25. Tajsharghi H, Kimber E, Kroksmark AK, Jerre R, Tulinius M, Oldfors A (2008) Embryonic myosin heavy-chain mutations cause distal arthrogryposis and developmental myosin myopathy that persists postnatally. Arch Neurol 65(8):1083-1090

26. Lagrutta AA, McCarthy JG, Scherczinger CA, Heywood SM (1989) Identification and developmental expression of a novel embryonic myosin heavy-chain gene in chicken. DNA 8(1): $39-50$

27. Ruppel KM, Spudich JA (1996) Structure-function analysis of the motor domain of myosin. Annu Rev Cell Dev Biol 12: $543-573$

28. Toydemir RM, Rutherford A, Whitby FG, Jorde LB, Carey JC, Bamshad MJ (2006) Mutations in embryonic myosin heavy chain (MYH3) cause Freeman-Sheldon syndrome and Sheldon-Hall syndrome. Nat Genet 38(5):561-565

29. Oana S, Machida S, Hiratsuka E, Furutani Y, Momma K, Takao A, Matsuoka R (1998) The complete sequence and expression patterns of the atrial myosin heavy chain in the developing chick*. Biol Cell 90(9):605-613

30. Reiser PJ, Portman MA, Ning XH, Moravec CS (2001) Human cardiac myosin heavy chain isoforms in fetal and failing adult atria and ventricles. Am J Physiol Heart Circ Physiol 280(4): H1814-H1820

31. Somi S, Klein ATJ, Houweling AC, Ruijter JM, Buffing AAM, Moorman AFM, van den Hoff MJB (2006) Atrial and ventricular myosin heavy-chain expression in the developing chicken heart: strengths and limitations of non-radioactive in situ hybridization. J Histochem Cytochem 54(6):649

32. Wessels A, Anderson RH, Markwald RR, Webb S, Brown NA, Viragh SZ, Moorman AFM, Lamers WH (2000) Atrial development in the human heart: an immunohistochemical study with emphasis on the role of mesenchymal tissues. Anat Rec 259(3):288-300

33. Wessels, Vermeulen JLM, Vir A, Gh S, Kalman F, Lamers WH, Moorman AFMA (1991) Spatial distribution of "Tissue-Specific" antigens in the developing human heart and skeletal muscle. II. An immunohistochemical analysis of myosin heavy chain isoform expression patterns in the embryonic heart. Anat Rec 229(3):355-368

34. Buttrick PM, Malhotra A, Brodman R, McDermott L, Lam L (1986) Myosin isoenzyme distribution in overloaded human atrial tissue. Circulation 74(3):477

35. Schaub MC, Hefti MA, Zuellig RA, Morano I (1998) Modulation of contractility in human cardiac hypertrophy by myosin essential light chain isoforms. Cardiovasc Res 37(2):381-404

36. Harridge SDR, Bottinelli R, Canepari M, Pellegrino M, Reggiani C, Esbj O, Rnsson M, Balsom PD, Saltin B (1998) Sprint training, in vitro and in vivo muscle function, and myosin heavy chain expression. J Appl Physiol 84(2):442-449

37. Larsson L, Moss RL (1993) Maximum velocity of shortening in relation to myosin isoform composition in single fibres from human skeletal muscles. J Physiol 472(1):595-614

38. Rutland CS, Polo-Parada L, Ehler E, Alibhai A, Thorpe A, Suren S, Emes RD, Patel B, Loughna S (2011) Knockdown of embryonic myosin heavy chain reveals an essential role in the morphology and function of the developing heart. Development 138(18):3955-3966

39. Sharma S, Taegtmeyer H, Adrogue J, Razeghi P, Sen S, Ngumbela K, Essop MF (2004) Dynamic changes of gene expression in hypoxia-induced right ventricular hypertrophy. Am J Physiol Heart Circ Physiol 286(3):1185-1192

40. Acharyya S, Ladner KJ, Nelsen LL, Damrauer J, Reiser PJ, Swoap S, Guttridge DC (2004) Cancer cachexia is regulated by selective targeting of skeletal muscle gene products. J Clin Invest 114(3):370-378

41. Sambrook JG, Russell R, Umrania Y, Edwards YJ, Campbell RD, Elgar G, Clark MS (2002) Fugu orthologues of human major histocompatibility complex genes: a genome survey. Immunogenetics 54(6):367-380

42. Barrett JC, Fry B, Maller J, Daly MJ (2005) Haploview: analysis and visualization of $\mathrm{LD}$ and haplotype maps. Bioinformatics 21(2):263-265

43. Nei M, Roychoudhury AK (1974) Sampling variances of heterozygosity and genetic distance. Genetics 76(2):379-390

44. Stephens M, Smith NJ, Donnelly P (2001) A new statistical method for haplotype reconstruction from population data. Am J Hum Genet 68(4):978-989

45. Allen DL, Leinwand LA (2001) Postnatal myosin heavy chain isoform expression in normal mice and mice null for IIb or IId myosin heavy chains. Dev Biol 229(2):383-395

46. Rutland C, Warner L, Thorpe A, Alibhai A, Robinson T, Shaw B, Layfield R, Brook JD, Loughna S (2009) Knockdown of alpha myosin heavy chain disrupts the cytoskeleton and leads to multiple defects during chick cardiogenesis. J Anat 214(6):905-915

47. Ching YH, Ghosh TK, Cross SJ, Packham EA, Honeyman L, Loughna S, Robinson TE, Dearlove AM, Ribas G, Bonser AJ, Thomas NR, Scotter AJ, Caves LS, Tyrrell GP, Newbury-Ecob RA, Munnich A, Bonnet D, Brook JD (2005) Mutation in myosin heavy chain 6 causes atrial septal defect. Nat Genet 37(4): 423-428

48. Oldfors A (2007) Hereditary myosin myopathies. Neuromuscul Disord 17(5):355-367 